\title{
SUPPLY CHAIN MANAGEMENT AND OPERATIONAL PERFORMANCE IN NIGERIA: A PANEL REGRESSION MODEL APPROACH
}

\author{
SHOBAYO P. B. ${ }^{1}$ \\ Olabisi Onabanjo University
}

\begin{abstract}
The research examined the effect of supply chain management on firm's operational performance in Nigeria manufacturing companies with specific interest on supply chain strategy and supply chain flexibility. A random effect model was developed to examine whether there is a significant effect on the variables identified, and the level of significance that exist in the variables. This study adopts an ex post-facto type of descriptive research design using Secondary sources to generate the data. The data were gathered from the annual report of manufacturing companies between 2011 and 2016. Findings revealed that supply chain management does not have a significant overall effect on operational performance at Prob value $=0.343$ which is above the sig. level of $<.005$, and the magnitude of variation which supply chain management cause on operational performance is $7.6 \%$ for all the companies samples which is significantly low. Hence, it is recommended that the management of a company's supply chain do not necessarily affect their operations; thus organizations can adopt a combination of strategies and flexibilities in their level of operation.
\end{abstract}

\section{KEYWORDS}

Supply chain, Strategy, Flexibility, Performance.

\section{INTRODUCTION}

The dynamics of business atmosphere has placed important challenges on business organizations. As compared to the traditional business environment, firms nowadays have entered a new edge of business environment that is more competitive and complicated (Chen \& Lin, 2009). As a result, the success of a firm does not only depend on its individual performance, rather on a complex chain of firms engaging in various roles.

Increasing competition has made supply chain flexibility and strategy an important emerging issue for businesses (Kumar, Fantazy, Kumar \& Boyle, 2006). Flexibility could be the capacity to adjust to changes in product mix, production volume, or design as well as reaction to environmental uncertainty. In general, flexibility is defined as the ability of an organization to efficiently and effectively adapt to foreseen and unforeseen changes (Tummala, Philips \& Johnson, 2006). The definitions of manufacturing flexibility play an important role in defining supply chain flexibility

\footnotetext{
${ }^{1}$ Corresponding address: Department of Business Administration, Faculty of Social \& Management Sciences, Olabisi Onabanjo University, Ago - Iwoye, Ogun State, Nigeria. Email: shobayopeterbabatunde@gmail.com
} 
(Kumar et al., 2006). But as the supply chain extends beyond the enterprise, supply chain flexibility must also extend beyond one firm's internal flexibility (Clos, Vokurka \& Lummus, 2003).

Operational performance can be defined as the level up to which products and services supplied by an organization meet the customer expectation. It provides an indication of the potentiality of the supply chain in providing products and services to the customer. This metric is most important in supply chain management as it integrates (involves) the measurement of performance right from supplier end to the customer end.

Recent studies have considered the effect of supply chain management on the financial performance of the organization using different dimensions and measurements of supply chain management such as supply integration, customer integration, internal integration, lean production, postponement concept, production performance, product quality, and delivery performance. However, there have been few researches on the effect of SCM on operational performance in the context of supply chain strategy and supply chain flexibility as far as the knowledge of the researcher is concerned (Arawati, 2011; Mohamed, Abdellatif \& Fakher, 2012; Hamid \& Hamid, 2014). This research intends to address the research gap by studying the effect of supply chain management in the context of supply chain strategy and supply chain flexibility on the operational performance of the organization. This is necessary as there have been past researches which have tested SCM against other organizational outcomes like profitability, productivity, and customer satisfaction; yet, few studies have studied the effect on the operational performance of the organization.

In addressing the research gap, the study provides answers to certain questions such as: what overall effect does supply chain management have on the operational performance of the organization? To what extent does supply chain strategy significantly affect operational performance? And how does supply chain flexibility affect operational performance? In line with these questions, the study will aim ta examining the effect of supply chain management on operational performance of the organization in the context of supply chain strategy and supply chain flexibility.

\section{LITERATURE REVIEW}

\section{Supply Chain Management}

Supply chain management (SCM) is a set of managerial practices which includes sourcing raw materials, manufacturing and assembling products, managing warehousing and inventory, monitoring supply and demand, distributing and delivering finished products to the customer (Windischer \& Grote, 2003; Agus, 2010). Various definitions have been used to explain the term SCM. Schonsleben (2004) defines SCM as coordination of strategic and long-term cooperation in logistics networks (Windischer \& Grote, 2003).

According to Quinn (1997), the supply chain management includes all of those activities associated with moving goods from the raw-materials stage through to the end user. This includes sourcing and procurement, production scheduling, order processing, inventory management, transportation, warehousing and customer service. SCM also embodies the information systems which are necessary to monitor all of those activities.

Ganeshan \& Harrison (1999) define supply chain as a network of facilities and distribution options that performs the functions of procurement of materials, transformation of these materials into intermediate and finished products, and the distribution of these finished products to customers. Supply chain management is integrated philosophy in the management of the distribution progress from supplier to final user. Supply chain management is a guiding concept of functional integration beyond individual firms onto networks of organizations (Gilaninia, Chirani, Ramzani \& Mousavian, 2011). 


\section{Supply Chain Flexibility}

The concept of flexibility in supply chain management is the ability of a business process to effectively manage or react to changes with little penalty in time, cost, quality or performance (Viswanadham \& Raghavan 1997). On the other hand, Lee (2004) explains the flexibility of supply chains as the ability of a company in terms of three distinctive components. These components are: One, adaptable: Adjust the supply chain's design to meet structural shifts in markets, modify supply network strategies, products and technologies. Two, alignment: Create incentives along the partners within the supply chain for better overall performance. Three, agility: The ability of a supply chain to respond to short-term changes in demand or supply quickly and handle external disruptions smoothly.

According to Vickery, Calantone \& Droge (1999), a manufacturing system is said to have flexibility, when it achieves the ability of reacting to changes faster and in a less costly manner in a way that system effectiveness will be less influenced. Given that flexibility is important but pursuing high flexibility is costly, there should be an assessment on how much flexible a supply chain should be.

Nemeth (2008) defined flexibility as consisting of two dimensions, temporal and intentional. In expanding the framework he identified four dominant dimensions of flexibility in his literature. The first is temporal; how long it takes an organization to adapt. The second is range; the number of options that an organization has open to it for change that was foreseen and the number of options it has available to react to unforeseen change. The third is intention; whether the organization is being proactive or reactive. The final dimension of flexibility is focus; specifically whether the flexibility is gained internally to the organization or by managing external relationships with trading partners.

\section{Supply chain strategy}

As global sourcing and offshore manufacturing dramatically alter the landscape of business activity, there needs to be a similar change in the way in which supply chain strategies are determined (Christopher, Peck \& Towill, 2006). Whilst downward pressure on price will continue to be a real issue in deflationary market conditions, it has also to be recognized that agility and responsiveness are increasingly fundamental to competitive success (Christopher et al., 2006). The typical supply chain strategy is likely to be aimed at achieving a smooth flow at minimum cost (Harrington, 1991; Scott \& Westbrook, 1991). But how are the right supply chain decisions to be made which will enable the defined business and marketing strategy to be enacted, literature shows a number of articles on supply chain strategy.

Katz, Bloodgood \& Pagell (2003) presented three active supply chain community strategies and one passive strategy. The active strategies are modularizing, appending and innovating. The passive strategy is following. Modularizing occurs when the community switches from selling individual inputs to selling complete sub-assemblies, or bundles of services (Katz et al., 2003). Appending means that the supply community bundles goods or services that are presently available elsewhere, with the existing goods or services in the hope of gaining additional profit from end consumers. Innovating adds one significant potential benefit to the supply community: a good or service not previously offered, following simply means to mimic the behavior of other suppliers (Katz et al., 2003).

\section{Performance}

The most effective relationships exist where supply chain partners have been made aware of what performance standards they are being held accountable for (Stuart \& McCutcheon, 2000). Selecting performance measures is intended to make sure companies accomplish the specific (collaborative) goals that they set. The supply chain performance measures that an organization sets for itself and 
others should be specific, measurable and evaluated at regular intervals, and whatever measures are selected should be enforced (Tummala, Philips \& Johnson, 2006).

Supply chain companies have realized the importance of financial and non-financial performance measures (Fantazy, Kumar \& Kumar, 2010). An effective performance measurement system ought to cover all aspects of performance that are relevant for the existence of an organization and the means by which it achieves success and growth (Kaplan \& Norton, 1996; Hillman \& Keim, 2001). This means that any performance measurement system ought to include more than just financial measures. This point is well established as many authors contend that any credible model of performance measurement must have more than one criterion (O'Regan \& Ghobadian, 2004).

Ali \& Güven (2009) carried out a study on Supply Chain Management as a Sustainable Performance Booster for the Accommodation Enterprises. Their objective was to access the supply chain practices of the hotels and to reveal effects of such practices on the hotels' performance. The survey instrument was adopted from previously used and tested measures of past researchers. The result showed that there is positive relationship between the supply chain practices of the hotels and their performance.

Sachin \& Vincent (2010) carried out a research on exploring the relationship between efficient supply chain management and firm innovation: An archival search and analysis. The data was generated from an archival financial statement information and patent citation data for firms in the manufacturing sector, over a 10-year period from 1987 to 1996. Longitudinal analysis, focusing on the influence of efficient supply chain management on a firm's innovation over time, was conducted. The results of the research indicate that over time a firm's supply chain performance and supply chain stability positively influence the volume of its innovations.

Furthermore, Arawati (2011), studied Supply chain management, supply chain flexibility and business performance. The researcher's objective was to examine the importance of incorporating supply chain management in Malaysian manufacturing companies. The study was a quantitative, cross-sectional research utilizing primary data. The overall result suggests that supply chain management has significant correlations with supply chain flexibility and business performance. Specifically, supply chain flexibility and business performance have high correlations with SCM comprising programs such as 'strategic supplier partnership', 'lean production', 'postponement concept' and 'technology and innovation'.

Adebayo (2012) conducted a study on the impact of SCM practices on SCM Performance. The SCM practices considered in this paper were namely strategic supplier partnership, customer relations practices, information sharing, information quality and postponement. The research provides empirical justification for five key dimensions of SCM practices identified and describes the relationship among SCM practices and SCM performance as well as the impact of these practices on SCM performance. The study thus showed that SCM practices definitely impacts SCM performance.

Somuyiwa, Mcilt, \& Adebayo, (2012) carried out a research on firm's competitiveness through supply chain responsiveness and supply chain management practices in Nigeria. They focused on 115 manufacturing companies as their sample size and adopted multiple regression analysis for the analysis. Results indicated a positive association between supply chain responsiveness, supply chain management practices and competitive advantage.

Arawati (2015) carried out a study on the influence of supply chain management on production performance and product quality. The researcher's objective was to examine the importance of incorporating supply chain management (SCM) in the Malaysian manufacturing industry and investigate its impact on production performance and product quality. A measurement Smart PLS model was developed and refined with reliability and validity tests more; Pearson's correlation 
analysis was conducted to establish associations between SCM practices, production performance and product quality. The findings revealed that SCM has a positive and significant effect on production performance. In addition, SCM also has a positive and significant effect on product quality.

Njoku \& Kalu (2015) carried out a research on the effective supply chain management as a strategic tool for profitability enhancement in the competitive marketing environment (Empirical evidence in the Nigerian food and beverage industry 2005-2014). Data was collected from annual reports of various issues and analyzed using inferential statistics such as pearson correlation model and simple regression analysis. Findings revealed that after investing heavily, their supply chain components do not significantly reflect in their profitability.

In line with the reviewed literature, the following hypotheses were postulated:

$\mathrm{H}_{01}$. Supply chain management has no overall significant effect on organizational operational performance.

$\mathrm{H}_{02}$. Supply chain strategy has no significant effect on the operational performance of an organization.

$\mathrm{H}_{03}$. Supply chain flexibility has no significant effect on operational performance of an organization.

\section{METHODOLOGY}

This study adopts an ex post-facto type of descriptive research design. This is because the design creates a causal relationship between the variables identified after the event. The target population for this study consists of twelve manufacturing companies in Nigeria which engages in consumer goods between 2011 and 2016. Consumer manufacturing companies are selected because of their engagement in supply chain with the final consumers of their products; hence, the companies are vital to this research work. The sample size for this study consists of top six manufacturing companies which produces consumer products, which were selected purposively on the basis of highest market capitalization, and whose financial data were available online annually between 2011 and 2016.

This research makes use of a secondary data, with the researcher having no control over the variables under study. The data were generated from the annual reports of the selected companies from 2011 to 2016. The variables in this study are divided into two which include the independent variable and the dependent variable. The independent variable identified is supply chain management which is measured by supply chain strategy and supply chain flexibility which are proxies on inventories and distribution cost respectively while the dependent variable is operational performance which is proxy on net cash generated from operating activities. Thus, it is specified that operational performance is dependent on supply chain management.

A mathematical model whose variable is adapted from the research of Arawati (2011) is used to explain the relationship between the dependent variable (operational performance) and the independent variable (supply chain management). The mathematical equation below therefore shows the effect of the independent variable on the dependent variable in a linear form as thus:

$\mathrm{OP}=\mathrm{f}($ SCSTRA, SCFLEX)

Where: OP $=$ Operational performance

SCSTRA = Supply chain strategy

SCFLEX = Supply chain flexibility

This can be specifically expressed in explicit form as:

$\mathrm{OP}_{\text {it }}=\alpha 0+\alpha 1$ SCSTRA $_{\text {it }}+\alpha 2$ SCFLEX $_{\text {it }}+\mathrm{Ut}$ 
Where $\mathrm{U}=$ stochastic or random error term (with usual properties of zero mean and non-serial correlation).

$\alpha 1-\alpha 2=$ Co-efficient of associated variables

$\alpha 0=$ Constant Intercept.

Due to the large figures involved in the data, a log- linear form is more likely to find evidence of a deterrent effect than a linear form; the equation is therefore log-linearized as follows:

LOGOP $_{i t}=\alpha 0+\alpha 1$ LOGSCSTRA $_{\text {it }}+\alpha 2$ LOGSCFLEX $_{\text {it }}+\mathrm{Ut}$

\section{Measurement of Variables}

\section{Operational Performance}

The operational performance of the organization is the cash flow from the operating activities of the companies. The net cash generated by operating activities of each company is used as proxy to measure the operational performance in the study and this is derived from the annual reports of the companies by adding the values of the cash receipts from customers and the cash generated from operations while deducting from the cash payments to suppliers and employees, value added tax received, and the income tax paid.

\section{Supply chain Strategy}

Supply chain strategy is a strategy which can either set up universality and integration in trade activities (purchasing, producing, selling and logistics) which is carried out in the length of chain, or set up maximum value for end users, and for setting up this strategy, the activities should be applied that improve cooperation and confidence relation between chain participants (Wisner, 2003; Cohen $\&$ Roussel, 2005). The supply chain strategy deals with the measures taken by the companies in distributing their products to the consumers. Inventories are used as proxy for supply chain strategy of an organization. Inventories are used as they show to an extent the type of strategy and the chain of network the organization adopts in making their goods available to the consumers. A lower inventory implies that the firm adopts the just in time or zero stock style, and transfers directly to the consumers without necessarily having distribution centers to store their goods, while a high inventory cost implies that the organization makes high usage of distribution centres and rely more on the middle men in the chain of distribution to transfer their goods to the consumer.

\section{Supply chain Flexibility}

The supply chain flexibility focuses on how flexible the companies are in distributing their products. The study used distribution cost as proxy for supply chain flexibility. These distribution costs determine to some extent how an organization is flexible in its supply chain. The higher the distribution cost, the more flexible the organization is in its supply chain.

The study utilizes a descriptive and inferential statistics to establish the effect of supply chain management on operational performance. The descriptive statistics help to describe and understand the characteristics of the variables under study and it includes the mean, median, variance and standard deviation. The inferential statistics meanwhile assists in drawing inferences from the panel data which was analyzed based on the pooled OLS, fixed effect model and random effect model. The data gathered are analyzed using E-views (v7).

\section{RESULTS}

Table 4.1: Descriptive Statistics

\begin{tabular}{|l|l|l|l|}
\hline & Flexibility & Strategy & Operational Performance \\
\hline Mean & 22.39005 & 23.11069 & 23.34875 \\
\hline Median & 22.19584 & 23.11063 & 23.60026 \\
\hline
\end{tabular}




\begin{tabular}{|l|l|l|l|}
\hline Maximum & 24.53157 & 24.59283 & 25.39433 \\
\hline Minimum & 19.89058 & 21.31702 & 20.08312 \\
\hline Std. Dev. & 1.398261 & 0.968950 & 1.359151 \\
\hline Skewness & 0.085042 & -0.489236 & -0.701078 \\
\hline Kurtosis & 1.943289 & 2.480740 & 2.851847 \\
\hline Jarque-Bera & 1.431947 & 1.533798 & 2.484985 \\
\hline Probability & 0.488714 & 0.464451 & 0.288664 \\
\hline Sum & 671.7016 & 693.3208 & 700.4626 \\
\hline Sum Sq. Dev. & 56.69890 & 26.66795 & 53.57146 \\
\hline Observations & 36 & 36 & 36 \\
\hline
\end{tabular}

Source: E-views output (2017)

Table 4.1 shows the generated data and the descriptive statistics descriptive statistics on supply chain flexibility, supply chain strategy and operational performance respectively. The Table reveals that the mean values for the variables are positive: $22.39,23.11$ and 23.34 respectively, and that supply chain flexibility have the largest average change value. The Table further revealed that the minimum change and the maximum change are positive in each case. This implies that each of the variables have positive changes throughout the sampling period. It is more so revealed in the Table that supply chain flexibility has the highest standard deviation which implies that it is the most volatile factor among the variables. The Table also shows that supply chain flexibility have a positive skewness, while supply chain strategy and operational performance have a negative skewness indicating that the right tail is particularly extreme for supply chain flexibility. Subsequently, the Table revealed that all the variables are platikurtic which implies that they are thinly tailed. Similarly, the Jarque-Bera (JB) statistic indicated that there is evidence of normality for all the variables.

Table 4.2: Pooled Regression Model

Dependent Variable: Operational Performance

Method: Panel Least Squares (pooled OLS)

Samples: 2011-2016

Periods included: 6

Cross sections included: 6

Total panel (balanced) observations: 36

\begin{tabular}{|l|r|r|c|r|}
\hline \multicolumn{1}{|c|}{ Variable } & Coefficien & Std. Error & t-Statistic & Prob. \\
\hline C & 7.275962 & 6.307572 & 1.153528 & 0.2588 \\
\hline FLEXIBILITY & 0.430305 & 0.162639 & 2.645768 & 0.0134 \\
\hline STRATEGY & 0.278582 & 0.237147 & 1.174724 & 0.2504 \\
\hline R-squared & 0.250135 & Mean dependent var & 23.34875 \\
\hline Adjusted R-squared & 0.194590 & S.D. dependent var & 1.359151 \\
\hline S.E. of regression & 1.219765 & \multicolumn{2}{|l|}{ Akaike info criterion } & 3.329834 \\
\hline Sum squared resid & 40.17134 & Schwarz criterion & 3.469953 \\
\hline Log likelihood & -46.94750 & Hannan-Quinn criter. & 3.374659 \\
\hline F-statistic & 4.503248 & Durbin-Watson stat & 0.798934 \\
\hline Prob(F-statistic) & 0.020524 & \multicolumn{3}{|l}{} \\
\hline
\end{tabular}

Source: E-views output (2017)

Table 4.3: Fixed Effect Model

Dependent Variable: Operational Performance

Method: Panel Least Squares (fixed effect)

Samples: 2011-2016

Periods included: 6

Cross sections included: 6

Total panel (balanced) observations: 36

\begin{tabular}{|c|r|r|r|r|}
\hline Variable & Coefficien & Std. Error & t-Statistic & Prob. \\
\hline $\mathrm{t}$ & & & \\
\hline $\mathrm{C}$ & 30.97070 & 23.31765 & 1.328208 & 0.1977 \\
\hline
\end{tabular}




\begin{tabular}{|c|c|c|c|c|}
\hline FLEXIBILITY & 0.584252 & 0.497626 & 1.174077 & 0.2529 \\
\hline STRATEGY & -0.895835 & 1.291662 & -0.693552 & 0.4952 \\
\hline & \multicolumn{2}{|c|}{ Effects Specification } & & \\
\hline \multicolumn{4}{|c|}{ Cross-section fixed (dummy variables) } & \\
\hline R-squared & 0.761084 & \multicolumn{2}{|c|}{ Mean dependent var } & 23.34875 \\
\hline Adjusted R-squared & 0.685065 & \multicolumn{2}{|c|}{ S.D. dependent var } & 1.359151 \\
\hline S.E. of regression & 0.762743 & \multicolumn{2}{|c|}{ Akaike info criterion } & 2.519388 \\
\hline Sum squared resid & 12.79910 & \multicolumn{2}{|c|}{ Schwarz criterion } & 2.893040 \\
\hline Log likelihood & -29.79081 & \multicolumn{2}{|c|}{ Hannan-Quinn criter. } & 2.638922 \\
\hline F-statistic & 10.01178 & \multicolumn{2}{|c|}{ Durbin-Watson stat } & 2.132457 \\
\hline Prob(F-statistic) & 0.000014 & & & \\
\hline
\end{tabular}

Source: E-views output (2017)

The fixed effect model indicated that probability value of supply chain flexibility and supply chain strategy are at $25.2 \%$ and $49.5 \%$ respectively which is above the $5 \%$ significant level. It can hence be said that supply chain flexibility and supply chain strategy do not have a significant effect on operational performance.

Table 4.4: Random Effect Model

Dependent Variable: Operational Performance

Method: Panel EGLS (cross-section random effects)

Samples: 2011-2016

Periods included: 6

Cross sections included: 6

Total panel (balanced) observations: 36

Swamy and Arora estimator of component variances

\begin{tabular}{|c|c|c|c|c|}
\hline Variable & $\begin{array}{r}\text { Coefficien } \\
\mathrm{t}\end{array}$ & Std. Error & t-Statistic & Prob. \\
\hline $\mathrm{C}$ & 13.36481 & 11.65644 & 1.146561 & 0.2616 \\
\hline FLEXIBILITY & 0.376958 & 0.283085 & 1.331608 & 0.1941 \\
\hline STRATEGY & 0.066801 & 0.520979 & 0.128223 & 0.8989 \\
\hline & \multicolumn{2}{|c|}{ Effects Specification } & & \\
\hline & & & S.D. & Rho \\
\hline \multicolumn{3}{|l|}{ Cross-section random } & 1.290714 & 0.7412 \\
\hline \multicolumn{3}{|l|}{ Idiosyncratic random } & 0.762743 & 0.2588 \\
\hline & \multicolumn{2}{|c|}{ Weighted Statistics } & & \\
\hline R-squared & 0.076149 & \multicolumn{2}{|c|}{ Mean dependent var } & 5.965776 \\
\hline Adjusted R-squared & 0.007716 & \multicolumn{2}{|c|}{ S.D. dependent var } & 0.748136 \\
\hline S.E. of regression & 0.745244 & \multicolumn{2}{|c|}{ Sum squared resid } & 14.99549 \\
\hline F-statistic & 1.112754 & \multicolumn{2}{|c|}{ Durbin-Watson stat } & 2.064346 \\
\hline \multirow[t]{2}{*}{ Prob(F-statistic) } & 0.343260 & & & \\
\hline & \multicolumn{2}{|c|}{ Unweighted Statistics } & & \\
\hline R-squared & 0.223333 & \multicolumn{2}{|c|}{ Mean dependent var } & 23.34875 \\
\hline Sum squared resid & 41.60720 & \multicolumn{2}{|c|}{ Durbin-Watson stat } & 0.744003 \\
\hline
\end{tabular}

Source: E-views output (2017)

The random effect model also indicated that the two values of the two variables do significantly not affect operational performance at 5\% significance level. The probability values of supply chain flexibility and supply chain strategy are at $19 \%$ and $89 \%$ respectively hence, making it insignificant on operational performance. In order to select the appropriate model for the hypothesis. The Hausman test is carried out. The Hausman test specifies that the fixed effect model is appropriate where the Probability value is $<5 \%$ and statistically significant, while the random effect model is appropriate where the $\mathrm{P}$ value $>5 \%$ and is not statistically significant. Thus random effect is appropriate for the null hypothesis while the random effect model is appropriate for the alternate hypothesis. 


\begin{tabular}{|c|c|c|c|c|}
\hline \multicolumn{4}{|c|}{$\begin{array}{l}\text { Table 4.5: Hausman Test } \\
\text { Correlated Random Effects - Hausman Test }\end{array}$} & \\
\hline \multicolumn{4}{|c|}{ Equation: Untitled } & \\
\hline \multicolumn{4}{|c|}{ Test cross-section random effects } & \\
\hline \multicolumn{2}{|c|}{ Test Summary } & $\begin{array}{l}\text { Chi-Sq. } \\
\text { Statistic }\end{array}$ & Chi-Sq. d.f. & Prob. \\
\hline \multirow{2}{*}{\multicolumn{4}{|c|}{\begin{tabular}{l|c} 
Cross-section random & 0.775318 \\
Cross-section random effects test comparisons:
\end{tabular}}} & 0.6786 \\
\hline & & & & \\
\hline Variable & Fixed & Random & $\operatorname{Var}$ (Diff.) & Prob. \\
\hline FLEXIBILITY & 0.584252 & 0.376958 & 0.167495 & 0.6125 \\
\hline STRATEGY & -0.895835 & 0.066801 & 1.396971 & 0.4154 \\
\hline
\end{tabular}

Source: E-views output (2017)

The result of the Hausman test in table 4.5 showed that the $\mathrm{P}$ value is $65.9 \%$ indicating that the probability value is greater than $5 \%$, thus it is not statistically significant. Thus, the pooled regression model in table 4.2, and the fixed effect regression model in table 4.3 are not relied upon as they do not indicate the appropriate model for discussion based on the Hausman test. This implies that the random effect model in table 4.4 is the appropriate model to analyze the effect of supply chain management on operational performance in the manufacturing sector. The random effect model indicates that the companies have a common mean value for the intercept.

From the analysis result of the random effect model in Table 4.4, it is discovered that the probability value of supply chain flexibility and supply chain strategy respectively are not statistically significant at $5 \% \mathrm{sig}$. level. The probability values of the two independent variables are $19 \%$ and $89 \%$ respectively. This implies supply chain strategy and supply chain flexibility have no statistical significant effect on operational performance.

The random effect model in Table four is thus used to test the hypotheses. As revealed by the model, the overall effect of supply chain management on operational performance in the manufacturing sector is not significant at 5\% because it show a probability statistic of $34 \%$, and an $\mathrm{R}$ squared value of $7.6 \%$. This indicates that the magnitude of variation caused on operational performance is $7.6 \%$ for all the companies sampled. The model further revealed that there is no significant individual effect of supply chain flexibility and supply chain strategy on operational performance. This is as seen in Table 4 that the probability value for supply chain flexibility is $19 \%$, while the probability value of supply chain strategy is $89 \%$. Hence the two variables do not have a statistical effect on operational performance. Thus the study fails to reject the three null hypotheses in this study which states that supply chain management has no overall significant effect on organizational operational performance, supply chain strategy has no significant effect on the operational performance of an organization, and supply chain flexibility has no significant effect on operational performance of the organization.

\section{CONCLUSION}

This study examines the effect of supply chain management on operational performance of an organization, with specific interest on supply chain strategy and supply chain flexibility of the organization. A random effect model was developed to examine whether there is a significant effect on the variables identified, and the level of significance that exist in the variables. Having developed the model, the study proceeds to test the underlying hypotheses towards achieving the research objectives.

The first objective is to evaluate the overall effect of supply chain management on organizational operational performance. The result revealed that supply chain management does not have a 
significant overall effect on operational performance, and the magnitude of variation which supply chain management cause on operational performance is $7.6 \%$ for all the companies' samples which is significantly low.

The second objective examines the effect of supply chain strategy on operational performance of an organization, and it was discovered from the result of the appropriate random effect model that supply chain strategy does not have a statistical significant effect on operational performance at $89 \%$ probability level which is above the $5 \%$ significant level.

The final objective determines the effect of supply chain flexibility on operational performance of an organization, and it was also discovered by the model that supply chain flexibility do have a statistical significant effect on operational performance at a probability level of $19 \%$ which is above the accepted significant level of $5 \%$.

The discussion in the previous section indicates that the study has been able to provide meaningful insight into the effect of supply chain management on the operational performance of manufacturing companies in Nigeria. The study has shown that supply chain management indices do not affect the operational performance of companies operating in the Nigerian manufacturing sector. Consequently the major conclusion drawn from this study are discussed in line with the objectives identified in chapter one and it discovered by the researcher that supply chain management do not have a significant overall effect on operation performance of organizations, More so, the study concluded that the supply chain strategies which are adopted by companies do not have an effect on their operational performance, and the study finally concludes that the different types of flexibility being utilized by companies do not affect their operational performance.

From the preceding discussions and conclusion, it is recommended that the management of a company's supply chain do not necessarily affect their operations; hence organizations can adopt a combination of strategies and flexibilities in their level of operation. Organizations however, should give more concern to their financial and overall performance. In doing this, organizations should seek to adopt the most effective and efficient method of managing their supply chain so that they can fully optimize their overall financial performance.

\section{REFERENCES}

Adebayo, I. T. (2012). Supply chain management (SCM) practices in Nigeria today: impact on SCM performance. European Journal of Business and Social Sciences, 1(6), 107- 115.

Agus, A. (2010). Supply chain management, process performance and business performance. Conference of the International Journal of Arts and Sciences, Rome, Italy, 22-25.

Ali, O., \& Güven, S. (2009). Supply chain management as a sustainable performance booster for the accommodation enterprises: evidence from North Cyprus tourism sector. International Journal of Business and Management, 4(2), 97-111.

Arawati, A. (2011). Supply chain management, supply chain flexibility and business performance. Journal of Global Strategic Management, 5(1), 134-145.

Arawati, A., (2015). Supply chain management: the influence of SCM on production performance and product quality. Journal of Economics, Business and Management, 3(11), 1046-1053.

Barney, J. (1991). Firm resources and sustained competitive advantage. Journal of Management, 17(1), 99-120. 
Chen, H. J., \& Lin, T. C. (2009). Exploring source of the variety in organizational innovation adoption issues: an empirical study of managers' label on knowledge management project issues in Taiwan. Expert Systems with Applications, 36(2), 1380-1390.

Christopher, M., Peck, H., \& Towill, D. (2006). A taxonomy for selecting global supply chain strategies. The International Journal of Logistics Management, 17(2), 277-287.

Dash, S., Bruning, E. D., \& Guin, K. K. (2007). Antecedents of long-term buyer-seller relationships: a cross cultural integration. Academy of Marketing Science Review, 11, 1 28.

Dyer, J. H., and Singh, H. (1998). The relational view: cooperative strategy and sources of inter-organizational competitive advantage. Academy of Management Review, 23(4), 660-679.

Fantazy, K. A., Kumar, V., \& Kumar, U. (2010) Supply management practices and performance in the Canadian hospitality industry. International Journal of Hospitality Management, 29(4), 685-693.

Ganeshan, R., \& Harrison, T. P. (1999). An introduction to supply chain management. Online internet, http // silmaril.smeal.psu.edu / misc / supply_chain_intro.html.

Gilaninia, S. H., Chirani, E., Ramzani, E., \& Mousavian, S. J. (2011). The impact of supply chain management practices on competitive advantage. Interdisciplinary Journal of Contemporary Research in Business, 3(6), 577-587.

Hamid, K., and Hamid, R. A. (2014). Study of performance measurement practices in supply chain management. Proceedings of the 2014 International Conference on Industrial Engineering and Operations Management Bali, Indonesia, January 7 - 9, 273-285.

Harrington, H. J. (1991). Business process improvement. McGraw-Hill, New York, NY.

Holcomb, T. R., \& Hitt, M. A. (2007). Toward a model of strategic outsourcing. Journal of Operations Management, 25, 464-481.

Kaplan, R. S., \& Norton, D. P. (1996). The balanced scorecard: translating strategy into action. Harvard Business School Press, Boston, MA.

Katz, J. P., Bloodgood, J. M., \& Pagell, M. D. (2003). Strategies of supply communities. Supply Chain Management: An International Journal, 8(4), 291-302.

Kumar, V., Fantazy, K., Kumar, U., \& Boyle, T. (2006). Implementation and management framework for supply chain flexibility. Journal of Enterprise Information Management, 19(3), 303-319.

Lee, H. L. (2004). A triple-A supply chain. Harvard Business Review, 82(10), 102-112.

Mohamed, M. D., Abdellatif, B., \& Fakher, J. (2012). Supply chain flexibility and balanced scorecard: conceptual model and empirical study in Tunisian companies launched upgrading program. Polish Journal of Management Studies, 5, 34-59.

Nemeth, P. (2008). Flexibility in supply chain management. Acta technical Jaurinesis Series Logistica, 1.

Njoku, M. E., \& Kalu, A. O. U. (2015). Effective supply chain management: a strategic tool for profitability enhancement in the competitive marketing environment (an empirical evidence in the Nigerian food and beverage Industry 2005 - 2014). European Journal of Business and Management, 7(13), 234-248.

O'Regan, N., \& Ghobadian, A. (2004). The importance of capabilities for strategic direction and performance. Management Decision, 42(2), 292-313.

Peteraf, M. A. (1993). The cornerstones of competitive advantage: a resource based view. Strategic Management Journal, 14, 179-191.

Quinn, F. J. (1997). What's the buzz? Logistics Management, 36(2), 43-7.

Rungtusanatham, M., Salvador, F., Forza, C., \& Choi, T. Y. (2003). Supply-chain linkages and operational performance: a resource-based-view perspective. International Journal of Operations and Production Management, 23, 1084-1099. 
Sachin, B. M., \& Vincent, A. M. (2010). Exploring the relationship between efficient Supply chain management and firm innovation: an archival search and analysis. Journal of Supply Chain Management, 46(4), 81-94.

Schonsleben, P. (2004). Integrated logistics management: planning and control of comprehensive supply chains. Boca Raton, FL.: St, Lucie Press.

Scott, C., \& Westbrook, R. (1991). New strategic tools for supply chain management. International Journal of Physical Distribution and Logistics Management, 19(2), 13 33.

Somuyiwa, A., Mcilt, M., \& Adebayo, T. I. (2012). Firm's competitiveness through supply chain responsiveness and supply chain management practices in Nigeria. British Journal of Arts and Social Sciences, 10(1), 42-52.

Toften, K., \& Olsen, S. O. (2003). Export market information use, organizational knowledge and firm performance: a conceptual framework. Industrial Marketing Review, 20(1), 95-110.

Tomkins, C. (2001). Interdependencies, trust and information in relationships, alliances and networks. Accounting, Organizations and Society, 26(2), 161-191.

Tummala, R., Philips, C., \& Johnson, M. (2006). Assessing supply chain management success factors: a case study. Supply Chain Management: An International Journal, 11(2), 179-192

Vickery, S. R., \& Calantone, C. D. (1999). Supply chain flexibility: an empirical study. The Journal of Supply Chain Management, 16-24.

Viswanadham, N., \& Srinivasa, R. N. R. (1997). Flexibility in manufacturing enterprises. Sädhanä, 22(2), 135-163.

Wilson, D. T. (1995). An integrated model of buyer-seller relationships. Journal of the Academy of Marketing Science, 23(4), 335-345.

Windischer, A., \& Grote, G. (2003). Success factors for collaborative planning, in Seuring, S., Miller, M., Goldbach, M., and Schneidewind, U. (Eds), Strategy and Organizations in Supply Chain, Physica, Heidelberg, 131-46. 